
pp. 1125-1142. 10.1080/01916599.2015.1077153. Downloaded from UCL Discovery: http://d isco very.ucl.ac.uk/1468950

\title{
ARTICLE
}

\section{Jeremy Bentham on Utility and Truth}

\author{
Philip Schofield \\ Bentham Project, Faculty of Laws, University College London \\ E-mail:p.schofield@ucl.ac.uk
}

\begin{abstract}
Jeremy Bentham has two very strong commitments in his thought: one is to the principle of utility, or the greatest happiness principle, as the fundamental principle of morality; the other is to truth, as indicated, for instance, in his opposition to falsehood and fiction in the law. How, then, did Bentham view the relationship between utility and truth? Did he think that utility and truth simply coincided, and hence that falsehood necessarily led to a diminution in happiness, and conversely truth led to an increase in happiness? This article address es this issue through two bodies of material: the first consists of Bentham's writings on religion under the heading of 'Juggernaut' and dating from 1811 to 1821; and the second consists of the writings on judicial evidence dating from 1803 to 1812 and which appeared in Rationale of Judicial Evidence.
\end{abstract}

Keywords: Evidence; fiction; religion; truth; utility.

\section{Fiction in Bentham's Fragment on Government}

In A Fragment on Government, which was first published in 1776, and which took for its target William Blackstone's Commentaries on the Laws of England ${ }^{1}$ Jeremy Bentham criticized Blackstone for heaping 'scorn upon those beneficent Legislators, whose care it has been to pluck the mask of Mystery from the face of Jurisprudence'. ${ }^{2}$ In discussing the Act of Parliament of $1730^{3}$ ordering that legal proceedings should be conducted in English, rather than in Latin, Blackstone had stated:

This was done, in order that the common people might have knowledge and understanding of what was alleged or done for and against them in the process and pleadings, the judgment and entries in a cause. Which purpose I know not how well it has answered; but am apt to suspect that the people are now, after many years experience, altogether as ignorant in matters of law as before. ${ }^{4}$

Bentham retorted that the statute in question had forced the lawyers, whose 'bigotry' or 'artifice' had led to much of the law being 'locked up in an illegible character', to relinquish 'their hieroglyphics, and to restore the native language to its rights'. He continued: 'This was

\footnotetext{
${ }^{1}$ William Blackstone, Commentaries on the Laws of England,4 vols (Oxford, 1765-9), quickly established itself as the authoritative guide to the English legal system.

2 Jeremy Bentham, 'A Fragment on Government' in A Comment on the Commentaries and A Fragment on Government (The Collected Works of Jeremy Bentham [hereafter CWJB]), edited by J.H. Burns and H.L.A. Hart (London, 1977) 410.

${ }^{3}$ Proceedings in the Courts of Justice Act (4 Geo. II, c. 26).

${ }^{4}$ Blackstone, Commentaries on the Laws of England, III 322.
} 
doing much; but it was not doing every thing. Fiction, tautology, technicality, circuity, irregularity, inconsistency remain. But above all the pestilential breath of Fiction poisons the sense of every instrument it comes near. ${ }^{5}$ Fiction was, in Bentham's view, not only a central problem in English law and hence in Blackstone's defence of it, but also in Blackstone's defence of the original contract as the legitimate basis of society, given that 'this chimera had been effectually demolished by Mr Hume'. ${ }^{6}$ In an accompanying footnote, a section that deals with volume three of Hume's Treatise on Human Nature is headed 'History of a mind perplexed by fiction'. Here Bentham explained that, 'no sooner had I read that part of the work that touches on this subject [utility], than I felt as if scales had fallen from my eyes. I then, for the first time, learnt to call the cause of the people the cause of Virtue.' He proceeded to give 'a short sketch of the wanderings of a raw but well-intentioned mind, in its researches after moral truth'. Bentham confessed that reading Clarendon on the civil war, ${ }^{7}$ together with 'The Genius of the place I dwelt in, the authority of the state, the voice of the Church in her solemn offices ... had listed my infant affections on the side of despotism'. ${ }^{8}$ Bentham had talked to lawyers who had extolled the notion of the original contract as a means of reconciling 'the general duty of submission' with 'the accidental necessity of resistance': this was, of course, the interpretation of the Glorious Revolution of 1688-9 that had been most famously put forward by John Locke in Two Treatises of Government and had become Whig orthodoxy. Bentham, however, wanted to be shown the historical basis for the contract, whereupon the lawyers, as Blackstone had done, had been forced to confess the whole to be a fiction. This, methought, looked ill. It seemed to me the acknowledgment of a bad cause, the bringing a fiction to support it. 'To prove fiction, indeed,' said I, 'there is need of fiction; but it is the characteristic of truth to need no proof but truth. Have you then really any such privilege as that of coining facts? ${ }^{9}$ You are spending argument to no purpose. Indulge yourselves in the licence of supposing that to be true which is not, and as well may you suppose that proposition itself to be true, which you wish to prove, as that other whereby you hope to prove it.' Thus continued I unsatisfying, and unsatisfied, till I learnt to see that utility was the test and measure of all virtue; of loyalty as much as any; and that the obligation to minister to general happiness, was an obligation paramount to and inclusive of every other. Having thus got the instruction I stood in need of, I sat down to make my profit of it. I bid adieu to the original contract: and I left it to those to amuse themselves with this rattle, who could think they needed it. ${ }^{10}$

Here we see Bentham in search of an account that was true, and it was because it struck him as true that he adopted the principle of utility.

Returning to the main text of Fragment on Government, in a paragraph headed 'Fictions in general mischievous in the present state of things', while admitting that ane time fictions might have had their use, ${ }^{11}$ Bentham announced that 'the season of Fiction is now over',

\footnotetext{
5 Bentham, 'Fragment', $411 \mathrm{n}$.

${ }^{6}$ Bentham, 'Fragment', 439.

${ }^{7}$ Edward Hyde, 1st Earl of Clarendon, The History of the Rebellion and Civil Wars in England, begun in the Year 1641,3 vols (Oxford, 1702-4).

8 The editors of the Collected Works edition of Fragment on Government suggest that 'The Genius of the place I dwelt in' is an allusion to Oxford: this is no doubt correct, but there may be a double entendre here, in that it may also allude to his father Jeremiah, who had very strong Tory sentiments. For a lively account of Bentham's relationship with his father see M.P. Mack, Jeremy Bentham: An Odyssey of Ideas 1748-1792 (London, 1962), 33-35, 50-55. Mack's book is, on the whole, more readable than reliable.

${ }^{9}$ Cf. 'Comment on the Commentaries' in Comment on the Commentaries and Fragment on Government, 45 : 'For it is a right that is claimed by our Author [Blackstone] in common with his fellow dealers in fiction, when they speak of a matter of fact as being necessary to any purpose, (for instance to justify a Law or measure) to suppose it to exist, although it does not, nay even though they own it does not.'

${ }^{10}$ Bentham, 'Fragment', 439-41 n.

${ }^{11} \mathrm{Cf}$. 'Comment on the Commentaries', 124-25, where Bentham complained about 'that curtain of mystery which fiction and formality have spread so extensively over Law', and commented that Blackstone had embroidered it with flowers. 'Almost all these fictions and these formalities ... formerly spoke truth. An
} 
since a practice that might previously have been tolerated under the name of fiction would now be termed an 'incroachment or imposture.'. ${ }^{12} \mathrm{He}$ went on to argue that a promise should be kept only to the extent that it promoted utility to do so, and hence a promise by the people to obey government, such as characterized the original contract, should only be kept to the extent that the government promoted the happiness of the people: in other words, people should obey government 'so long as the probable mischiefs of obedience are less than the probable mischiefs of resistance'. ${ }^{13}$ Throughout this discussion, truth and fiction are constantly opposed-as in the following phrases 'to quit the fiction, and resume the language of plain truth' and 'to pass any sound decision upon the question which the inventors of this fiction substituted instead of the true one'. ${ }^{14}$ Again in 'Comment on the Commentaries', in a fragmentary passage dealing with the original contract, Bentham remarked:

But it is the way with Lawyers, and above all with this Lawyer [Blackstone]: they can no more speak at their ease without a fiction in their mouths, than Demosthenes without pebbles. Such is the power of professional prejudice to deprave the understanding.

They feed upon untruth, as the Turks do upon opium, at first from choice and with their eyes open, afterwards by habit, till at length they lose all shame, avow it for what it is, and swallow it with greediness, not bearing to be without it. ${ }^{15}$

As well as opposing truth on the one side to fiction on the other, Bentham identified the former with what was right and proper, and the latter with what was wrong and improper. This opposition remained constant throughout Bentham's career. In the 'Preface for the Second Edition' of Fragment on Government, for instance, probably written in 1822 but not published when the second edition eventually appeared in 1823, Bentham resumed the attack he had made in the first edition of 1776 on the notion of the original contract. The 'fable' of the original contract, he remarked, invented by Whig lawyers, was the 'offspring of falsehood and sinister interest', and 'it was the offspring of Fiction; meaning here by the word Fiction, that which is meant by it in law-language'. He continued: 'A fiction of law may be defined-a wilful falsehood, having for its object the stealing legislative power, by and for hands, which could not, or durst not, openly claim it,-and, but for the delusion thus produced, could not exercise it.'16

The point, and it is one that has not been given sufficient attention in Bentham scholarship, is that Bentham committed himself not only to the value of utility, but also to that of truth. If he had indeed adopted the principle of utility because it was true, this would suggest that truth was the ultimate value in Bentham's thought, contrary to the received opinion that utility performed that role. What, then, was the relationship between truth and utility, and which should be regarded as the starting-point for Bentham's thought? I will consider three alternatives: ${ }^{17}$ first, that utility was subordinate to truth, in the sense that one was morally

unwillingness to acknowledge the departure keeps them fast in use, long after truth has slipped aside from them.'

12 Bentham, 'Fragment', 441.

${ }^{13}$ Bentham, 'Fragment', 441-45.

14 Bentham, 'Fragment', 443.

15 Bentham, 'Comment on the Commentaries', 58-59.

16 Bentham, 'Fragment', 509. The passage continues (509-11) with a condemnation of legal fictions, on the grounds that they were intended to produce profit for lawyers, and vitiated the understandings of the people, and that the fact that men had been persuaded 'to regard falsehood, as an instrument, not only serviceable but necessary to justice' was a measure of 'the degree of debility produced'. The aim was to make morality dependent on the wills of the possessors of power, 'and in regard to truth', to give them 'the power of determining, if not what shall be truth, what, to all practical purposes, shall be taken for it'.

${ }^{17}$ It might be argued that truth and utility were independent, in the sense that truth might be seen to belong to the realm of fact and utility to the realm of value. This is not a view to which I will give consideration here, on the grounds that Bentham did not adhere to a fact/value distinction in the sense that it came to be accepted in twentieth-century legal philosophy. See Philip Schofield, 'Jeremy Bentham and H.L.A. Hart's "Utilitarian Tradition in Jurisprudence”, Jurisprudence, 1 (2010), 147-67, where I argue that, for Bentham, utility statements, or statements of value, were themselves reducible to factual statements. 
obliged to be truthful whatever the consequences in terms of utility; second, that truth was subordinate to utility in the sense that one took to be true whatever promoted utility; and third, that truth and utility were mutually supportive in the sense that whatever was true was useful and whatever was useful was true. The issue is addressed more concretely through asking whether, in Bentham's view, it was possible for a fiction or a falsehood to promote utility, that is produce an increase in human happiness or a decrease in human suffering? Or to put this another way, was it possible for truth to produce evil, that is a decrease in human happiness or an increase in human suffering? Take the problem famously discussed by Emmanuel Kant about whether to inform a person intent on murder where he might find his proposed victim. To tell the truth would result in the violent death of an innocent person, but to lie would be morally wrong. ${ }^{18}$ What would Bentham's advice have been? The most obvious answer is that he would have advised us to choose the lesser evil, and tell a lie. But in that case, would it not be as much as to say that truth was subordinate to utility, and would such an admission not undermine his opposition to legal fictions and the original contract? And would it not more generally undermine his repeated appeals to truth?

Before proceeding it is important to emphasize the distinction between a fiction and a fictitious entity in Bentham's thought. Much Bentham scholarship has been plagued by an assumption that a fictitious entity is a fiction, ${ }^{19}$ no doubt as a result of C.K. Ogden's unfortunate choice of the title Bentham's Theory of Fictions for his re-hashed presentation of Bentham's writings on logic and language. ${ }^{20}$ For Bentham, a fiction was a falsehood, ${ }^{21}$ whereas the name of a fictitious entity was an abstract term. Having noted, for instance, that 'Religion is the name of a fictitious entity', Bentham remarked that this did not mean 'the religion in question, be it what it may, is not true'. ${ }^{22}$ The fact that a word was the name of a fictitious entity did not mean that a sentence containing that word was a falsehood, that is a fiction. Indeed, before ascertaining whether a proposition containing a fictitious entity was true, one had to ask whether it made sense. If the fictitious entity had its real source in the physical world, then a proposition containing it had meaning, and might be true or false; if the fictitious entity did not have a real source, it was a non-entity, and the proposition made no sense, and it made no sense to ascribe truth or falsehood to nonsense. Bentham continued:

To give to the word [religion] a determinate meaning - to bring to view the relation borne by this fictitious entity to real ones, it will be necessary to make up this word, together with other words, into a phrase: and thereupon to shew the equivalence (the equivalence is - not between word and word, but between phrase and phrase) as between the phrase in which this name of a fictitious entity is the principal word, and the phrase containing the name of some corresponding real entity.

This technique of exposition was termed 'paraphrasis' by Bentham. This is not to say that Bentham did not think that there was an element of fiction in the name of a fictitious entity. The fiction lay in the way in which such names were 'dressed up in the garb, and placed upon the level, of real ones', a 'contrivance' without which language, at least above the level

\footnotetext{
18 Kant's 'On a proposed right to lie because of philanthropic concerns' first appeared in 1799, and was a response to an argument advanced by Benjamin Constant, which was in turn a response to an argument advanced by 'a German philosopher': see http://philpapers.org/rec/KANOAS-2 [accessed 19 May 2015]. ${ }^{19}$ In his essay on Bentham's theory of probability (though it is in large measure concerned with Bentham's ontology), G.J. Postema, for instance, refers indiscriminately to fictions and fictitious entities: see 'Fact, Fictions, and Law: Bentham on the Foundations of Evidience', in Facts in Law, edited by W. Twining (Wiesbaden, 1983), 37-64. A further error made by some commentators, and which seems to originate with Mack, Bentham: Odyssey of Ideas, 180-84, is that Bentham's logic of the will is concerned with fictions. ${ }^{20}$ Bentham's Theory of Fictions, edited by C.K. Ogden (London, 1932). A more expressive title would have been 'Bentham on the Names of Real and Fictitious Entities', but that might not have sounded quite so appealing.

${ }^{21}$ For a plain statement by Bentham that a fiction was a falsehood see First Principles preparatory to Constitutional Code (CWJB), edited by P. Schofield (Oxford, 1989), 267.

22 Grote Papers, British Library Additional MS 29,809, fo. 9 (7 March 1819).
} 
of that employed by animals, could not exist. ${ }^{23}$ Bentham emphasized two points. The first was that there was a danger of assuming that, because the names of entities, whether real or fictitious, all took the form of noun substantives, and because the names of real entities corresponded to objects or things that could be said to exist, there were existing objects or things that corresponded to the names of fictitious entities. ${ }^{24}$ The second point was that the use of the names of fictitious entities was extremely beneficial-to the extent that it raised the human species above the level of animals, it might be regarded as the basis of civilization itself. ${ }^{25}$ If fiction or falsehood even in this very limited and precise sense was so very useful, does it not again suggest that truth was subordinate to utility? In trying to make some progress in understanding Bentham's view of the relationship between utility and truth, I will focus first on Bentham's 'Juggernaut' manuscripts, and second on his Rationale of Judicial Evidence.

\section{Juggernaut}

Bentham's 'Juggernaut' manuscripts, in which he mounted a wide-ranging critique of religious belief, were composed between 1811 and 1821. The heading 'Juggernaut', or 'Jug' for short, was the term that Bentham adopted to characterize religion. ${ }^{26}$ The significance of 'Juggernaut' to the theme of this article is that Bentham explicitly distinguished between the questions of the utility of religion and its verity or truth, and used this distinction as the central organizing principle of the material as a whole. He arranged his manuscripts under the main headings of 'Jug. Util.' and 'Jug. True' or 'Jug. Verity'. In 'Jug. Util.' he investigated whether religious belief was conducive to happiness in the present life. In 'Jug. True', he addressed the question of the truth of religion. I will begin by focusing on one essay in the 'Juggernaut' material, namely 'The Usefulness of Religion, with reference to the present life, examined', which was written in the spring of 1819. A man was a believer in religion, explained Bentham, to the extent that he assumed the existence of an invisible and superhuman being, by whom provision has been made of a system of rewards and punishments to be eventually administered to individuals of the human species-either in the present or in a future life, or in both'. In practice, such belief gave rise to the desire to avoid displeasing the superhuman being in the hope of obtaining reward, or at least avoiding punishment. Religion itself was divided into two branches, natural and revealed. A believer in revealed religion believed that the superhuman being, or some man or men who had communicated with that being, had laid down a rule of action, together with a system of rewards and punishments for enforcing its observance. There was, in other words, direct evidence of the rule of action and associated sanctions. A believer in natural religion entertained the same belief regarding the existence of the rule of action and associated sanctions without any direct, but only with circumstantial, evidence. Hence, believers in natural religion had commonly believed that the rule of action most conducive to the greatest happiness of the greatest number would be enforced by the superhuman rewards and punishments. ${ }^{27}$

\footnotetext{
${ }^{23}$ Bentham Papers, University College London Library [hereafter UC], Box cii, fo. 23 (23 September 1814).

${ }^{24}$ See also UC ci. 322 (7 August 1814).

25 See also UC ci. 142 (28 July 1814), where Bentham, having explained that a faculty of the mind was 'a sort of person or instrument, purely fictitious', and that the operations performed by the faculty were partly real and partly fictitious, stated: 'Misrepresentation in this form-falshood in a word, for so, in so far as the falshood is considered as pure from guilt in every shape, it may with strict truth be stiled-falshood, howsoeverpregnant with, and in no slight degree fertile in, deception, is not the less indispensably necessary to the several purposes - the purest not less than to the most impure - of language.'

${ }^{26}$ For a description of the 'Juggernaut' manuscripts see C. Fuller, "'Utility of Religion a subject little as yet examined": A Survey of Bentham's writings on the utility of religion', Revue d'études benthamiennes, 6 (2010) http://etudes-benthamiennes.revues.org/74 [accessed 20 May 2015]. George Grote drew on this material to produce Philip Beauchamp [pseud.], Analysis of the Influence of Natural Religion on the Temporal Happiness of Mankind (London, 1822).

${ }^{27}$ BL Add. MS 29,809. fos. 10-11 (7 March 1819). Bentham no doubt had William Paley in mind as the most prominent exponent of the view that has come to be known as 'theological utilitarianism'. For Bentham's
} 
Bentham's target in 'Usefulness of Religion' was natural religion, leaving revealed religion for a subsequent essay. He began with the question of utility. If religion were to be useful, argued Bentham, then it would either provide rules that promoted human happiness, or provide sanctions to such existing rules as already did so: 'If, then, so it be that in any way the tendency of religious belief is to be upon the whole useful or contributory to the encrease of happiness - of the greatest happiness of the greatest number, it must be either by means of a directive rule afforded by it, or by means of the sanction afforded by it, or by means of both together.' The questions, therefore, that Bentham addressed, were whether natural religion, without the aid of revealed religion, was capable of providing any directive rule at all; if it did so, whether any such rule was conducive to the greatest happiness, or whether, in contrast, it promoted misery instead; and in relation to its provision of a sanction, whether it was inefficient in promoting good, while efficient in promoting evil, that is 'substracting upon the whole from, more than it adds to, the sum of human happiness in the present life'?28 Bentham's view was that natural religion was incapable of providing either a rule of action or an effective sanction for rules derived from any other source that were conducive to human happiness in the present life. In relation to the provision of a rule of action, Bentham argued that if a believer in natural religion wished to know what line of action was required by the invisible creator, he would have to ask what line of action was most conducive to human happiness, for that was the only line of action that such a creator, on the supposition of his existence and his benevolence, could prescribe. The same question, however, would need to be asked independently of any supposition concerning the existence and benevolence of an invisible creator, and the only grounds for answering it would be 'experience and observation and induction'. ${ }^{29}$ In relation to the provision of an effective sanction, Bentham argued that the human sanctions-law and public opinion-were sufficient to promote human happiness, while the superhuman sanction tended to be destructive of, rather than conducive to, happiness in the present life. ${ }^{30}$

Pursue on all occasions that course of conduct which is most conducive to the sum of happiness - this is the command which ... the advocate of Natural Religion is able, and in a cultivated state of society seems generally disposed, to put into the mouth of the invisible and almighty being whose existence he supposes. Ask him what that course is, either he is altogether silent, or with or without acknowledging it, he referrs you to one or more or all of the ... purely human sanctions, and the corresponding rules which, by their application and operation, they respectively mark out. ${ }^{31}$

There is no need her to go into further details, but suffice it to say that Bentham concluded that belief in natural religion was detrimental to the greatest happiness of the greatest number. ${ }^{32}$

Bentham then turned to the question of the verity of natural religion. He noted that in order for religion to have 'any degree of usefulness ... in the present life, the belief of its verity - that is the persuasion of the existence of a posthumous life stocked with reward and punishment, or at least with punishment-is an indispensable accompaniment'. There were

\footnotetext{
engagement with Paley more generally see Philip Schofield, 'A comparis on of the moral theories of William Paley and Jeremy Bentham', Bentham Newsletter, 11 (1987), 4-22.

${ }^{28}$ BL Add. MS 29,809, fos. 98-100 (29 April 1819).

${ }^{29}$ BL Add. MS 29,809, fos. 86, 88-89 (16 February 1819).

${ }^{30}$ BL Add. MS 29,809, fo. 219 (17 February 1819). At the time that he composed this essay, Bentham recognized five human sanctions: the pathological, including the phy sical and the psychological; the retributive; the popular or moral; the political, including the legal and executive branches; and the sympathetic. The religious made a sixth sanction. See BL Add. MS 29,809, fo. 64 (17 February 1819).

${ }^{31}$ BL Add. MS 29,809, fo. 227 (18 February 1819). The directive rules prescribed by revealed religion, added Bentham, contributed 'prodigiously to the efficiency of natural religion to [the] mischievous, without making any perceptible addition to its efficiency with reference to the beneficial, purpose': see BL Add. MS 29,809, fo, 204 (19 February 1819).

${ }^{32}$ For further details see J.E. Crimmins, Secular Utilitarianism: Social Science and the Critique of Religion in the Thought of Jeremy Bentham (Oxford, 1990), 207-26, and P. Schofield, Utility and Democracy: The Political Thought of Jeremy Bentham (Oxford, 2006), 186-93.
} 
two insurmountable difficulties with the notion of an afterlife. The first was the issue of personal identity. There were no grounds for assuming that a human being in the present life would be the same human being who was presumed to exist in a future life. If the posthumous mind did not have a body in which to dwell, it was unclear what it would do to occupy itself, and even if the posthumous mind contained the same ideas as the earthly mind, it was incapable of adding to them by means of new impressions, since all sensations were derived through the body. If the posthumous mind was given a new body, then a new, material planet would be needed, and if so, where was it? And why should this new body be rewarded or punished for actions undertaken 'in and by another body so completely different from it?'33 The second difficulty lay in distinguishing between those who would experience the posthumous existence and those who would not, both in terms of different specieswould animals enter into the future state?-and in terms of human beings-would a baby or an idiot be admitted, and would they remain a baby or an idiot for eternity?-and if some were to be admitted, and others not, where would the line be drawn? ${ }^{34}$

Bentham turned his attention to the absurdities involved in the belief in an almighty being who was assumed to be all-wise, all-benevolent, and all-powerful. In relation to giving to man a directive rule, the all-wise being had not even condescended to give the sort of rule that a man might give to a dog, that is by chastising it when it did something that the man did not want it to do. By not knowing what God wanted, man thwarted God's desire by 'continually breaking the supposed corresponding imaginary command'. In order to give effect to his unknown desire, God applied punishment as a sanction-yet this punishment was useless, because no one knew what God's desire was. Such was hardly the action of a benevolent being. A human ruler was able to make known the rule of action that he wished others to obey and the sanctions that he would apply, but God was unable to do this. Yet God was supposed to be all-powerful. If the response was that this uncertainty showed the necessity of the revealed religion given to Moses and Jesus, then it did not help anyone who lived before Moses, nor anyone except Jews who lived after Moses and Christians after Jesus. Until the time of Moses, remarked Bentham, "here was either no God at all, or a God altogether void of all wisdom, of all benevolence, of all power'. How was it, asked Bentham, that at the time of Moses 'either this God started up out of nothing, or a God without any of those attributes being already in existence, those attributes accrued to him out of nothing?' Why did God create the world? and if at one time he was satisfied without performing such a task, why did he become dissatisfied? No action was motivated without a desire for pleasure and an aversion to pain, and what grounds were there for thinking that a being existed that would act without such motivation? If one simply did not believe in the all-wise, allbenevolent, and all-powerful being, there was no absurdity. ${ }^{35}$

Other questions that Bentham addressed under the heading of 'Verity' included the problem of evil-it did not make sense to attribute benevolence to an omnipotent God when there existed evil in the world; and the problem of creation-if God created the world, how did God come into existence? From what little experience we had, it was 'less strange' to think of the world as having no beginning than that of it having had a beginning at 'any determinate time'. ${ }^{36}$

Since, then, perception of truth is not the cause of ... this belief in the existence of a neverperceived yet all-productive being-where, then, are we to look for the cause-what, then, are the cause or causes? Answer. Fear and state-craft. Fear of itself would find the sanction: state-craft takes up the sanction, and with that in hand traces out a directive rule.

In savage tribes, you have the fear alone: the sanction alone....

\footnotetext{
${ }^{33}$ BL Add. MS 29,809, fos. 184, 186-87 (24-5 February 1819).

34 BL Add. MS 29,809, fos. 384-85, 389 (26 February 1819).

35 BL Add. MS 29,809, fos. 280-85 (29 April, 1 May 1819).

${ }^{36}$ BL Add. MS 29,809, fos. 143-53 (5 March 1819). Cf. BL Add. MS 29,809, 396 (n.d.): 'Observe, then, the dilemma. If sin can exist without an author, then so may any thing else: if sin can not exist without an author, then, as being the author of every thing, then is God the author of it.'
} 
In barbarous nations as well as civilized, you have the directive rule: a rule described by the ruling few, accommodated to their own notions of their own particular separate and sinister interests, and by a mixture of fraud and force, injected into the brains and heads of the subject multitude. ${ }^{37}$

Hence, in relation to the utility of religion, Bentham dealt with the consequences, in terms of human happiness, resulting from the inability of natural religion to provide either a determinate rule or effective sanctions, while in relation to the verity of religion, he dealt with the existence of God and the afterlife. ${ }^{38}$

One of Bentham's targets in 'Usefulness of Religion' was presumably William Warburton, who, in The Divine Legation of Moses Demonstrated, which had appeared in 1738, had made the following statement concerning the equivalence of utility and truth:

general Utility and all Truths necessarily coincide. For Truth is nothing but that Relation of things, whose Observance is attended with universal Benefit. We may therefore as certainly conclude that general Utility is always founded on Truth, as that Truth is always productive of general Utility. ${ }^{39}$

Warburton's argument was that 'the Truth of Religion in general' was proved 'from its infinite Service to human Society'. He continued:

Truth is productive of the good of the whole; and Truth only: for Falshood is productive of the Mischief of it: The first being the Observance of the Relations of Things, which Observance causes Happiness; and the latter, the Violation of those Relations, which Violation causes Misery. Wherever then we find universal Utility, we may certainly know it for the Product of Truth. But the Practice of Legislators shews us, that this Utility results from Religion: The Consequence is, that Religion is true..$^{40}$

Warburton was responding to critics of religion who had denied that religion was true either because it had no utility or, more commonly, because it was of so much utility that legislators had fabricated it, the latter view being that most commonly expressed by 'infidels'. ${ }^{41}$ For Warburton, then, utility, truth, and religion were mutually supportive. That Bentham, whom Warburton would no doubt have numbered amongst the 'infidels', had Warburton's position in mind is suggested when, in the 'Preface' to 'Usefulness of Religion', he wrote that: 'The opinion that seems generally prevalent is - that it [i.e. religion] is not only true but useful: useful, and to such a degree necessary, as that without it human society could not be kept together, if in any state, in any state comparable to that in which in this country we see it.' Bentham went on to say that 'a very considerable part of the whole number of thinking men in this country' did not believe religion to be true, but that the greater number of them believed that it was useful. They accepted that the maintenance of religious belief was 'a sort of fraud', but that its usefulness rendered the fraud not only excusable, but justifiable and necessary. ${ }^{42}$ Bentham's own position, as we have seen, was that belief in religion promoted human misery, and not human happiness, and that it was not true, but false. This does not, however, settle the question of how Bentham saw the relationship between utility and truth. Having disagreed with Warburton in arguing that religion was both opposite to utility and false, he may have still agreed with him that 'general Utility and all Truths necessarily

\footnotetext{
${ }^{37}$ BL Add. MS 29,809, fo. 348 (25 April 1819).

38 See, for instance, the discussion of original sin at BL Add. MS 29,809, fo. 398 (25 April 1819), where Bentham characterizes original sin as 'Original nonsense', since it involved disobedience to precepts that had never been articulated.

${ }^{39}$ William Warburton, The Divine Legation of Moses Demonstrated, on the Principles of a Religious Deist, From the Omission of the Doctrine of a Future State of Reward and Punishment in the Jewish Dispensation (London, 1738), 424.

${ }^{40}$ Warburton, Divine Legation, 417.

${ }^{41}$ Warburton, Divine Legation, 417-18.

42 BL Add. MS 29,809, fo. 352 (20 April 1819). This was a mild statement from the mature Bentham. At this time he would characteristically argue that religion was an instrument used by rulers in order to maintain their own wealth, power, and dignity. As he colourfully expressed it in his memorandum book of 1822-24 (UC clxxiii. 75): 'Religion is an engine, invented by corruptionists, at the command of tyrants, for the manufactory of dupes.'
} 
coincide'. I will turn now to Bentham's strategy in the 'Juggernaut' writings in order to investigate whether he did indeed accept the view that utility and truth coincided.

\section{Bentham's strategy in 'Juggernaut'}

The 'Juggernaut' project would have consisted in eight works, or rather in eight distinct parts of a single work. While there is no need here to try to unravel the details, Bentham intended to deal first with the utility and verity of natural religion, and then with the utility and verity of the revealed religion of Jesus. There are three issues to consider: first, why did Bentham consider utility before verity? second, what did he mean by verity? and third, did the utility of religion depend to any extent upon its verity? In 'Usefulness of Religion', Bentham explained that he had given priority-in terms of its being of most immediate importance-to the question of the utility of religion:

To the question concerning its utility, the question concerning its verity is but subordinate. Suppose it neither beneficial nor mischievous, its verity is not worth enquiry after; if asserted, there is no use in its being controverted. But if, upon the whole, it be detrimental to human happiness, then its verity is worth enquiry after: for on that supposition, the exclusion of the belief in its verity is beneficial. ${ }^{43}$

In a draft introduction to 'Jug. True', Bentham noted that had he not been satisfied that natural religion in general, and the religion of Jesus in particular, were mischievous upon the whole, he would not have gone on to consider the question of the truth of religion. 'The question relative to utility being settled,' he stated, 'what remains, viz. the question relative to truth, is a mere question of evidence.' ${ }^{44}$ In an alternative draft introduction, he noted that had the utility of religion not been found wanting, the question of its truth would not have been considered. He went on to explain that, 'In strictness of speech, propositions alone are the subjects of which truth, otherwise called verity, is an attribute'. In the case of the religion of Jesus, the propositions in question were 'enuntiative of some supposed matter of fact' which, supposing the propositions true, would prove the verity of the belief. The matters of fact in question were miracles and prophecies. ${ }^{45}$ Bentham's conclusion was that the doctrines attributed to Jesus by the authors of the Gospels were detrimental to utility and that there was no trustworthy evidence to support the truth of the accounts that they had given of his life. ${ }^{46}$

Hence, under the head of utility Bentham discussed 'the precepts and other doctrines' that were ascribed to Jesus by the authors of the Gospels, while under the head of verity he discussed 'the events comprized in the history of the life of Jesus', again as presented by the authors of the Gospels. ${ }^{47}$ He reiterated the distinction when he went on to describe 'the system of precepts' as 'unfavourable to the happiness of the community' and 'the narrations' as 'contrary to truth'. ${ }^{48}$ As an example of falsehood, Bentham referred to the story of the Star of Bethlehem, involving, as it did, an 'event or state of things' that was 'incompatible with the relative state of the earth and the other celestial bodies of the known world as established by astronomical observations and calculations'. ${ }^{49}$ Bentham's point here was related to his more general theory of evidence:

Every real matter of fact which has ever had place-every real and individual matter of fact, whether event or state of things, existing at a particular point of time ... every substance, being or individual as characterized by the name, whether proper or common, employed for the designation of it, has, at the time in question, had for its accompaniments an innumerable multitude of substances-either in motion or, in certain positions with relation to one another, at rest-all real as itself is: matters of fact constituting a circle of which it is the

\footnotetext{
${ }^{43}$ BL Add. MS 29,809, fo. 185 (19 February 1819).

${ }^{44}$ BL Add. MS 29, 806, fo. 423 (28 September 1815).

45 BL Add. MS 29,806, fos. 427-28 (18 January 1814).

46 BL Add. MS 29,806, fo. 503 (18 April 1819).

${ }^{47}$ BL Add. MS 29,806, fo. 227 (28 September 1815).

${ }^{48}$ BL Add. MS 29,806, fo. 230 (28 September 1815).

${ }^{49}$ BL Add. MS 29,806, fo. 233 (7 August 1815).
} 
center. To have had for its accompaniment the contents of a circle of this kind filled with real existences is the characteristic and distinguishing property of every such real matter of fact: not to have had any such accompaniments is the characteristic and distinguishing property of a false matter of fact, a merely imaginary matter of fact, which, by its unreality, gives to any statement by which its reality is asserted, the cha<rac>ter and denomination of a false one.

The two essential circumstances that belonged to every matter of fact were time and place. Bentham referred to such circumstances as 'marks of verity'. ${ }^{50}$ The account of the Star of Bethlehem, like the stories of other miracles ascribed to Jesus, was, for Bentham, lacking in marks of verity.

Although Bentham considered the question of the utility of religious belief before that of verity, he recognized that the very existence of religious belief, at least insofar as such belief was sincere, depended upon an acceptance of its verity. Hence, in another passage, having insisted on the importance of separating the consideration of the utility of religion from that of its verity, he explained that the former concerned the hopes and fears that religion produced, and the latter 'the groundedness or ungroundedness of those same expectations'. The influence exerted by religion depended on the good and evil that persons were persuaded or believed would result from the divine dispensation, not on what would in fact result. He continued:

though the verity of religion be not of itself necessary to any utility of which it may be productive, yet the belief-the persuasion-of its verity is necessary to the production of any such effect. But, of the persuasion of its verity, the extent in this as in any other instance can not but be more or less dependent on its verity: and in this indirect and remote way, though not in a direct and immediate way, its utility can not fail of being more or less dependent on its verity: in so much as, supposing it for argument sake demonstrated and believed that there exists not any foundation for the expectations in question, their influence on conducttheir influence good and bad together- ceases of course. utility. ${ }^{51}$

Thus it is that every objection against the verity of religion operates against its

In short, there was truth and there was belief as to what was truth. There was, on the one hand, the truth which consisted in physical reality or matters of fact-certain events had really happened-and, on the other hand, belief as to what had happened. Such beliefs, moreover, might be more or less true, in other words were more or less consonant with actual events - with physical reality. The truth of any belief could be assessed by evidence, that is the existence of other matters of fact that made the belief in question credible. If one did not believe in the truth of religion, Bentham appears to be saying, it would not influence one's conduct: 'it is only in so far as it is believed to be true that it can operate with any effect at all'. ${ }^{2}$ The point is reiterated elsewhere: 'The effects, good or bad, produced in the present life by religion, by the eventual expectation of supernatural punishment and supernatural reward, have for their immediate cause not the verity of religion, but the persuasion of its verity'. If no one believed in a supernatural dispensation, religion would have no effect on conduct, even though, as a matter of fact, those rewards and punishments would in fact be administered. In contrast, if people believed that the sanctions would be administered, even though in fact they would not, religion would influence conduct. ${ }^{53}$

In another passage, in apparent contradiction of this view, Bentham argued that there was no necessary or causal link between belief in the utility of religion and belief in its verity. Having explained that belief in the truth of religion concerned belief in the existence of a God who distributed rewards and punishments in the present or a future life, and that a believer in the temporal utility of religion was someone who accepted that belief in such a distribution was conducive to the well-being of mankind, Bentham noted that there were some who had

\footnotetext{
${ }^{50}$ BL Add. MS 29,806, fos. 434-35 (22, 26 August 1815).

${ }^{51}$ BL Add. MS 29,809, fos. 331-32 (6 February 1820).

52 BL Add. MS 29,809, fo. 332 (6 February 1820).

${ }^{53}$ BL Add. MS 29,809, fo. 298 (9 January 1821).
} 
believed in its truth but did not believe in its temporal utility-St Paul was an example-while there were others who did not believe in its truth, but did believe in its utility. ${ }^{54}$ The example of the ascetic St Paul did not undermine, but rather strengthened Bentham's first argument discussed above that a belief in the verity of religion influenced conduct, since St Paul was prepared to advocate suffering on the grounds of his belief that religion demanded it. ${ }^{55}$ The incongruity exists in the other case, where disbelief in its verity did not undermine disbelief in the utility of religion-the persons in question here being rulers who exploited religion for their own purposes. ${ }^{56}$ In this case, Bentham might have argued, it was in the particular interest of non-believing rulers to promote religion, whereas it was not in the interest of the members of the community as a whole to do so. Leaving this particular case out of the account, Bentham's standard view was that, as 'the human mind advances in strength', belief in the verity of religion would diminish, and eventually disappear. The influence of religion would disappear at the same time as belief: 'in this way the question of verity is constantly and almost inextricably interwoven with the question of usefulness'. He went on to explain again that the issue revolved around men's belief or persuasion concerning the verity of religion, rather than the actual truth. Bentham used the term 'absolute truth' to refer to 'truth without reference to human belief'-such truth, however, was 'of no effect and therefore no importance: only in so far as it is perceived by human eyes can truth be productive of effect on human hands'. ${ }^{57}$

In summary, in the first place, the question of the utility of religion put to one side the question of whether God existed or not, and asked simply whether a belief in a God who distributed rewards and punishments was conducive to human well-being. It was only when this question was answered in the negative that the question of the verity of religionincorporating such questions as whether there was a God, whether Jesus had a divine commission, whether there was an immortal soul-was worth considering. The point was that it was quite possible that belief in religion might have pernicious effects, yet that religion still be true. Bentham, however, argued not only that belief in religion was pernicious, but also that there was no trustworthy evidence in support of the truth of religion. What we have established up to this point is that Bentham posited an external reality which he termed, on one occasion, 'absolute truth', but that there was another sense of truth which might be termed subjective truth, and consisted of beliefs held by human beings and supported by some degree of appropriate evidence. A belief was only true, however, when it corresponded to 'absolute truth'. An examination of the 'Juggernaut' writings, therefore, gives us some reason to think that truth was regarded by Bentham as independent of utility: first, simply because verity could be treated as a separate question from that of utility; second, because religion might be regarded by some persons as useful, even though they did not believe it was true; and third, because 'absolute truth' was just what existed. As we have seen, in 'Juggernaut' Bentham commented that once the question relative to utility had been settled, the remaining question relative to truth was 'a mere question of evidence'. On the one hand, he regarded the question of utility as being of greater importance than verity; on the other hand, utility depended, at least to some extent, on verity. In the following section of this paper I will consider Bentham's theory of evidence to see what further light might be cast on his view concerning the relationship of utility and truth.

\section{Evidence}

The notions of truth, falsehood, and fact were addressed by Bentham in Book I of Rationale of Judicial Evidence. ${ }^{58}$ While not published until 1827, it should be noted that much of

\footnotetext{
${ }^{54}$ BL Add. MS 29,809, fos. 357-58 (22, 25 April 1815).

${ }^{55}$ For Bentham's views on the asceticism of St Paul see P. Schofield, Jeremy Bentham: Prophet of Secularism (The $80^{\text {th }}$ Conway Memorial Lecture) (London, 2012).

56 i.e. Warburton's 'infidels' and Bentham's 'corruptionists'.

${ }^{57}$ BL Add. MS 29,809, fo. 302 (9 January 1821).

${ }^{58}$ For an authoritative account of Bentham's views on judicial evidence see W. Twining, Theories of Evidence: Bentham and Wigmore (London, 1985), 19-108.
} 
Rationale of Judicial Evidence appears to have been written in 1803-5 and 1811-12, and so in the main pre-dates 'Juggernaut'. It seems reasonable to assume that, in the latter, Bentham was drawing on the conclusions reached in the former. Bentham's principal concern in Rationale of Judicial Evidence was with 'the discovery of truth' in the context of a trial at law, in order to ensure correct decision on the part of the judge. ${ }^{59}$ Evidence consisted of 'any matter of fact, the effect, tendency, or design of which, when presented to the mind, is to produce a persuasion concerning the existence of some other matter of fact: a persuasion either affirmative or disaffirmative of its existence'. The latter was the principal fact, and the former the evidentiary fact. ${ }^{60}$ In judicial procedure, evidence was 'a general name given to any fact, in contemplation of its being presented to the cognizance of a judge, in the view of its producing in his mind a persuasion concerning the existence of some other fact; of some fact by which, supposing the existence of it established, a decision to a certain effect would be called for at his hands'. ${ }^{61}$ The judge had to be secured against deceptionfrom being persuaded 'of the existence of some matter of fact which was not in existence'and thereby coming to a wrong decision. The legislator should assist the judge by providing instructions 'to guide him in judging of the probative force of evidence', and by taking measures to ensure 'that the evidence itself shall possess as great a degree of probative force, in other words, shall be as trustworthy as possible'. Trustworthiness of evidence was constituted by correctness and completeness. If a statement concerning a matter of fact were correct, then it was 'as conformable as possible, at least in respect of all material circumstances, to the facts themselves'. If it were complete, then the statements which constituted the evidence 'comprehend[ed], as far as possible, and without omission, the aggregate mass of all such facts, material to the justice of the decision about to be pronounced, as on the occasion in question really had place'. ${ }^{62}$ There was, however, a caveat in terms of the completeness of evidence. If it so happened that the collection of a piece of evidence was attended with such a degree of 'delay, vexation, and expense' that made it more likely that the mischief occasioned by the collection would outweigh the mischief of the chance of injustice, then it is better that the evidence in question be not presented than that it should be presented'. ${ }^{63}$ In other words, it was not truth at any price.

Bentham's theory of judicial evidence was derived from a more general theory of evidence:

Questions in natural philosophy, questions in natural history, questions in technology in all its branches, questions in medicine are all questions of evidence. When we use the words observation, experience, and experiment, what we mean is, facts observed, or supposed to be observed, by ourselves or others, either as they arise spontaneously, or after the bodies in question have been put, for the purpose, into a certain situation. ${ }^{64}$

A question in mathematics, such as whether two and two made four, and a question in natural religion, such as whether God existed, were alike in that they were questions of evidence. ${ }^{65}$ What, then, was a fact? Bentham made a classification of facts according to three divisions, although the divisions themselves were closely related: the first was a division between physical and psychological facts; the second between events and states of things; and the third between positive and negative facts. In relation to the first division, Bentham explained that a physical fact was 'considered to have its seat in some inanimate being: or, if in an animate being, by virtue, not of the qualities by which it is constituted animate, but of those which it has in common with the class of inanimate beings', while a

\footnotetext{
${ }^{59}$ See Jeremy Bentham, Rationale of Judicial Evidence, specially applied to English Practice, edited by John Stuart Mill, 5 vols (London, 1827), I, 1-2, 5, 8.

${ }^{60}$ Bentham, Rationale of Judicial Evidence, I, 17-18.

${ }^{61}$ Bentham, Rationale of Judicial Evidence, I, 24.

62 Bentham, Rationale of Judicial Evidence, I, 27-29.

63 31. The direct end of justice was rectitude of decision, while the indirect end was the avoidance of delay, vexation, and expense: see Bentham, Rationale of Judicial Evidence, I, 34.

${ }^{64}$ Bentham, Rationale of Judicial Evidence, I, 19.

${ }^{65}$ Bentham, Rationale of Judicial Evidence, I, 19-21.
} 
psychological fact was 'considered to have its seat in some animate being, and that, by virtue of the qualities by which it is constituted animate'. Hence, motion of itself was a physical fact, whereas voluntary motion was a complex fact, since, in addition to the physical fact of the motion, it involved an exertion of the will that preceded and caused the motion and which was a psychological fact. Psychological facts included sensations, recollections, judgments, desires, and volitions. ${ }^{66}$

Bentham's second division of facts was into events and states of things, that is states of motion and states of rest respectively. According to Bentham, 'a portion of matter', whether 'inanimate or animate', was either in motion or at rest. He explained that a state of rest was a relative term, since, as far as could be judged, all portions of matter were at all times in motion (for instance, the earth was in motion around the sun), and hence to say that two portions of matter were at rest was to describe their relationship to each other. An 'event' was 'some motion, considered as having actually come about in the course of nature'. All our discourse was concerned with either a state of things or an event, or both. Whether something was in a state of rest or whether something was in motion was a matter of fact:

A fact, then, or a matter of fact, is either the existence of two or more things, considered, in relation to one another, as being in a state of rest during successive portions of time,- - or an event; in the idea of which event is uniformly included that of motion on the part of some portion of matter, i.e. a change in its relative position to, and distance from, some other portion of matter.

An act or action was an event caused by human will, and was either external or purely internal. An external act, as we have already seen, was complex, in that it involved both the external action of the body and an antecedent act of the will, which was an internal act. An internal act, however, could take place without any external motion. The term motion was in this case applied to the mind, even though no motion as such could be observed, 'for, in speaking of what passes in the mind, we must be content, for the most part, to employ the same language as that which we employ in speaking of what passes in and about the body, or we could not in any way make it the subject of discourse'. ${ }^{67}$ It appears, then, that an internal human act involved a psychological fact, while an external human act involved both a psychological and a physical fact.

Bentham's third division was into positive and negative facts. This division could not, he explained, be applied to the facts themselves, which could only be positive, but to the discourse employed in speaking of them. A negative fact was merely the non-existence of a positive fact. He cautioned, however, that language could be deceptive. To say that someone enjoyed health appeared to assert a positive fact, but health did not exist as such-it was merely the non-existence of disease. The same was the case when we said that a place was dark, for darkness did not exist-it was merely the absence of light. ${ }^{68}$

In the context of a court of law, the point of the evidence was to persuade a judge that certain facts were true-in other words that the events and states of things that were alleged to have existed had actually existed. Bentham pointed out that not only might a person be completely persuaded that a fact existed or did not exist, but that he might possess 'different degrees of strength' of persuasion. ${ }^{69}$ Just as any ordinary person might be more or less persuaded by an account of some event, so the judge might be more or less persuaded by the testimony of witnesses at a trial. Bentham suggested that a scale should be adopted, where 1 to 10 indicated the degree of 'positive persuasion' in relation to the existence of a fact, -1 to -10 indicated the degree of 'negative persuasion', and 0 indicated 'the non-existence of any degree of persuasion on either side'. A witness, instead of merely stating that he believed either that some fact existed, or that it did not exist, or that he was unable to form any belief, would be able to give a numerical value to the strength of his belief

\footnotetext{
${ }^{66}$ Bentham, Rationale of Judicial Evidence, I, 45-7.

${ }^{67}$ Bentham, Rationale of Judicial Evidence, I, 47-49.

${ }^{68}$ Bentham, Rationale of Judicial Evidence, I, 49-50.

${ }^{69}$ That people held a variety of degrees of persuasion in relation to the probability of some future event was illustrated by the practices of betting and insurance.
} 
and thereby represent it more exactly. Each witness, where there was more than one, would do likewise. In pronouncing his decision, the judge would express the strength of his own persuasion according to the same scale. ${ }^{70}$ Bentham explained that he had used the term persuasion because that was 'the only term equally proper in all cases, that is, in all degrees'. The term opinion was not appropriate, for instance, since it was 'scarcely considered as being, like persuasion, susceptible of degrees'. The term belief, in ordinary discourse, seemed to be applied 'to designate any degree of persuasion', while among religionists, 'it is employed to designate the very highest degree, and to the exclusion of every other; since it is not any inferior degree that will satisfy them'. Among lawyers, on the other hand, the term belief had been used 'to designate any inferior degree of persuasion, to the exclusion of the highest', and the term knowledge to indicate the highest degree-in other words, knowledge was 'a degree of persuasion above belief'. ${ }^{71}$ The use of the notion of degrees of persuasion led to the collapse of any distinction between knowledge and belief, or more precisely, to the removal of those terms in a forensic context, and by extension across the whole range of arts and sciences.

Bentham argued that there existed 'a propensity to believe in testimony', a fact established by 'universal experience', and that it was right to give way to this propensity, a fact also established by experience. A person's prosperity or happiness depended on knowledge of 'the states of men and things', and the knowledge that one could gather from one's own direct experience was 'but a minute and altogether insufficient portion' of the knowledge that one needed in order to prosper. For the greater part of one's knowledge, one had to rely on testimony.

And what is it that, by thus rendering it a man's interest, renders it proper for him to bestow a general belief on testimony? It is the general conformity of testimony to the real state of things - of the real state of things to testimony: of the facts reported upon, to the reports made concerning them.

And by what is it that this conformity is made known? Answer again-by experience. It is because testimony is conformable to the truth of things, that, if you were to go on treating it as if it was not conformable, you would not fail of suffering from it.

The experience of the conformity of the facts themselves with the facts asserted in testimony was the cause of the persuasion produced by testimony. In most past instances testimony had been found to be true, and this gave rise to the disposition to believe it in future instances. On the other hand, in some instances the testimony had been found to be false, and this produced a disposition to disbelieve it. The predominance of instances in which testimony had conformed to fact over those in which it had not had given rise to the general tendency to believe, while disbelief occurred only in exceptional circumstances. Were it otherwise, were it the case that testimony could not be believed on the whole, society would collapse. ${ }^{72}$

Bentham pointed out that incorrectness and incompleteness in testimony, that is falsity in testimony, could result from a defect in either the intellectual faculties (perception, judgment, memory, and expression) or in the moral or volitional faculties (veracity and attention). It is important to draw attention to Bentham's distinction between veracity and

\footnotetext{
${ }^{70}$ For Bentham's description and defence of his persuasion scale see Bentham, Rationale of Judicial Evidence, I, 71-80. Bentham's method was founded on the recognition of 'a connection between ... persuasion on the part of a witness, probative force on the part of his testimony, and persuasion on the part of a judge, all susceptible of variation on one and the same scale'. The 'observation of the connection between these clearly distinguishable, though so closely connected, objects, was, as far as it goes, an observation in psychology - an observation made of the invariably observable phenomena of human nature'. See Bentham, Rationale of Judicial Evidence, I, 97.

${ }^{71}$ Bentham, Rationale of Judicial Evidence, I, 90-91.

72 Cf. Bentham, Rationale of Judicial Evidence, I, 97: 'The general prevalence of correctness and completeness over the opposite qualities in testimony, is a matter of fact out of the reach of dispute, and a state of things, the existence of which may be regarded as indispensably necessary to the existence of mankind: it is to the general predominance of the tutelary forces over the seductive, that this prevalence of truth over falsehood is to be as cribed.'
} 
mendacity on the one side, and between verity and falsity on the other. Veracity existed when it was the will or desire of the witness 'that his testimony, and the conclusions drawn from it, be conformable to the real state of the case', and mendacity when it was his will that it be 'in any respect unconformable to the real state of the case'. Verity had place when, whatever the state of his will, the testimony of the witness was conformable to the real state of the case, and falsehood or falsity when it was unconformable. It was possible that a witness who wished to render his testimony in this or that respect disconformable to the truth of the case' in fact rendered it conformable: in other words, the testimony of a mendacious witness, despite his own efforts, might nevertheless have the quality of verity. ${ }^{73}$ Given that all human action-and inaction insofar as a person took a decision not to actwas motivated by a desire for pleasure and an aversion to pain, the giving of testimony was motivated by the same desire and aversion. Motives could be conveniently grouped according to their source in four sanctions, namely (1) the physical, (2) the moral or popular, (3) the legal and political, and (4) the religious. Each of these sanctions could operate either to produce correctness and completeness in testimony, or incorrectness and incompleteness, but the general tendency was towards the former, that is truth, rather than the latter, that is falsehood. I will not deal here with Bentham's discussion of the latter two sanctions, the legal and political, and the religious, but confine myself to the former two.

Beginning with the physical sanction, which consisted of those pains and pleasures produced 'by the operation of causes purely natural', that is without the intervention of will, Bentham argued that its overriding tendency, because of the natural inclination to prefer ease to the pain of labour, was to operate in favour of veracity. 'To relate incidents as they have really happened', or more precisely as they had appeared to the narrator to have happened, 'is the work of memory: to relate them otherwise than as they have really happened, is the work of the invention. But, generally speaking, comparing the work of the memory with that of the invention, the latter will be found by much the harder work.' He continued:

The ideas presented by the memory present themselves in the first instance, and as it were of their own accord: the ideas presented by the invention, by the imagination, do not present themselves without labour and exertion. In the first instance come the true facts presented by the memory, which facts must be put aside: they are constantly presenting themselves, and as constantly must the door be shut against them.

It took much greater effort to fabricate and to maintain a lie, than simply to tell the truth.

Hence an axiom of mental pathology, applicable to the present case: an axiom expressive of a matter of fact, which may be stated as the primary and fundamental cause of veracity in man. The work of the memory, is in general easier than that of invention. But to consult the memory alone in the statement given, is veracity: mendacity is the quality displayed, so far as the invention is employed.

The love of ease, that is the desire to avoid mental exertion, was a motive that tended to keep men to the truth. The pain of exertion created by mendacity was the punishment that arose without the intervention of any person's will, and belonged, therefore, to the physical sanction, just as did the pain that arose from putting one's hand in the flame of a candle. ${ }^{74}$

By the first impulse, by the impulse of the universal principle above delineated [i.e. the axiom of mental pathology], by a sort of instinctive impulse, the line in which a man's discourse is urged is invariably the line of veracity-of truth: it is only by reflection, reflection on the distant advantage supposed to be obtainable by falsehood, that a man's footsteps can be turned aside out of that line. ${ }^{75}$

Having said that, it would on many occasions be easier to tell only part of the truth, rather than the whole of it. Hence, while testimony was likely to be correct, it might not be complete, since to give a complete account might require more effort than the witness was prepared to bestow. Were there no other sanction at work than the physical sanction, the

\footnotetext{
${ }^{73}$ Bentham, Rationale of Judicial Evidence, I, 156-7.

${ }^{74}$ Bentham, Rationale of Judicial Evidence, I, 202-04.

75 Bentham, Rationale of Judicial Evidence, I, 206.
} 
result would be that complete falsehood would never have place, but falsehood in some part of the account would be frequent: 'truth would, in every case, constitute the ground; but that ground would be frequently receiving a tincture of falsehood: and, the more complex and extensive the ground, the deeper and more extensive would the tincture be naturally apt to be'. ${ }^{76}$ The securing of truth in discourse was also promoted by a further interest that operated on many occasions, namely the fact that it is only by making known, and that truly, something that he thinks, that a man can obtain what he wants'. If we did not truly express what we desired, our desire would be frustrated. ${ }^{77}$

The second sanction that Bentham considered was the moral or popular sanction. Bentham repeated his view that happiness depended on knowledge, while knowledge itself depended upon true testimony: 'except in those cases of comparatively rare occurrence, in which falsehood itself serves to lead to truth, it is only in so far as it is expressive of truth, that testimony is productive of knowledge'. He noted that the reliance we placed on other people, whether under or outside the law, in relation to 'the innumerable and daily services, obligatory or free, which we stand in need of for the sustentation and comfort of our existence,- -all depends ... on the preponderance of men's disposition towards the side of veracity and truth'. The force of the moral or popular sanction, therefore, 'with only here and there a casual exception', operated 'constantly on the side of truth'. That it did so was shown by the infamy attached to those who were considered to be liars, and the resentment that the accusation provoked. ${ }^{78}$

In the main, and upon the whole, the force of the moral or popular sanction acts in a direction favourable to general happiness and virtue. In the main, accordingly, the direction taken by this same force is favourable to that particular branch of virtue which consists in veracity. ${ }^{79}$

There were, however, exceptions to this general rule. First, because of the general condemnation given to vicious conduct, insofar as someone had acted viciously, that person had an incentive to conceal the fact, and thus to lie about having done it. Second, where there was an opposition between the particular interest of some small group of individuals and the general interest of the community as a whole, the small group, composed for instance of thieves or smugglers, had an interest in the truth not being revealed insofar as it would result in their discovery and punishment. Another group with a particular interest were lawyers: '[u]nder every system, every mercenary lawyer-under the fee-gathering system, every lawyer without exception' had an interest 'as unquestionably, though not as uniformly, opposite to the general interest, as that which forms the bond of union in communities of thieves and smugglers'. Repeating the point he had made in Fragment on Government and on numerous occasions besides, Bentham complained that the result had been that the whole system of judicial procedure is one continued tissue of lies: of allowed, protected, rewarded, encouraged, and even necessitated, lies'. ${ }^{80}$

Yet, in contrast to these cases in which public opinion condemned mendacity, there were, noted Bentham, cases in which 'Mendacity is not only permitted, but in some cases properly permitted by the moral sanction.' He continued: 'That cases exist in which a departure from truth is, and ought to be, either prescribed, or at least allowed, by the moral or popular sanction considered in its true and largest sense is out of dispute.' While eschewing a full discussion of the question because of its 'intricacy and delicacy', Bentham identified four such cases. In the first case, where some mischief would result to another person from telling the truth, and no mischief would result from telling a lie, it was a duty not to tell the truth: for instance, where 'a madman or assassin, with a naked weapon in his

\footnotetext{
76 Bentham, Rationale of Judicial Evidence, I, 207-08.

77 Bentham, Rationale of Judicial Evidence, I, 208-09.

78 Bentham, Rationale of Judicial Evidence, I, 210.

79 Bentham, Rationale of Judicial Evidence, I, 212.

${ }^{80}$ Bentham, Rationale of Judicial Evidence, I, 212-19. Bentham stated that 'the great bulk of the community ... have no interest but in the universal prevalence of veracity'. See Bentham, Rationale of Judicial Evidence, I, 216.
} 
hand, asks whether his intended victim be not there, naming the place where he actually is'. Hence, the surmise offered above as to Bentham's view in this case was quite correct. The second case concerned 'falsehoods of humanity or beneficence, as when a physician, to save pain of mind, gives hopes which he does not entertain himself'. The third case concerned 'falsehoods of urbanity', which were falsehoods of humanity exercised in more trivial circumstances, for instance where one gives a better opinion of some production than one really entertains, in order not to discourage the producer. The fourth case was where a departure from truth was 'allowed, without being prescribed', that is where information was withheld from a person who had no right to it. Bentham recommended circumspection, however, in these last three cases. A man might do such 'irremediable mischief' to himself were he to acquire 'the reputation of habitual or frequent falsity', so that, 'if urged and pressed', the better course might be 'to give up the enterprise of humanity or urbanity, and declare, after all, the naked truth'. ${ }^{81}$

\section{Conclusion}

What, then, does this survey of Book I of Rationale of Judicial Evidence tell us about the relationship between utility and truth in Bentham's thought? Bentham argued, as we have seen, that there were occasions on which it was morally right-that is in accordance with the principle of utility - to utter a wilful or self-conscious falsehood. There were occasions when there was a moral duty not to tell the truth, and not only not to withhold correct and complete information, but to lie. Did this mean that truth was, after all and contrary to at least some of the indications given in 'Juggernaut', subordinate to utility? Such a conclusion, however, as pointed out above, would appear to undermine Bentham's critique of legal fictions on the ground that they were lies, but also lead to a tautology at the root of his philosophy. We have seen that, for Bentham, a truth was an accurate belief concerning facts, and that facts consisted of really existing events and states of things, that is of matter in motion and matter at rest. If truth were subordinate to utility, our beliefs and knowledge-both of which collapsed into the notion of degrees of persuasion-ought not to reflect what really existed, but what it would be useful-that is conducive to utility-to believe or to know. This is as much as to say that what we ought to believe is what we ought to believe.

Consider Bentham's distinction between veracity and mendacity on the one hand, and verity and falsity on the other. In Bentham's example of the assassin who wants to know whether his proposed victim is at a particular location, if the person answering had a true belief about the location of the proposed victim, he could then send the assassin to the wrong place. If he did not have a true belief about the location, he might send the assassin to the correct place, despite his desire not to do so-his discourse would possess the quality of verity, despite his mendacity. In the former case, the mendacious and untrue discourse promoted utility, while in the latter case, the mendacious but true discourse promoted disutility. The discourse of the disbeliever in religion who nonetheless promoted belief in religion was mendacious and untrue, albeit in this case his object was to promote his own utility at the expense of general utility. It was, on most occasions, conducive to utility to discourse with veracity, but not always. And so in the case of legal fictions and the social contract, Bentham's objection to them must have been not simply that they were lies, but that they were detrimental to utility. By adopting the distinction between verity and veracity, Bentham could explain why in certain cases it was conducive to utility to lie, yet remain in all cases conducive to utility to know the truth, that is to have a correct and complete degree of persuasion in relation to facts-in relation to what really existed. Moreover, it should not be forgotten that verity or truth was understood by Bentham in two senses. The notion of verity as 'absolute truth' pointed to the facts of the physical world, what really existed and what had really happened;

\footnotetext{
${ }^{81}$ Bentham, Rationale of Judicial Evidence, I, 219-21. For William Paley's list of 'falsehoods which are not lies, that is, which are not criminal, as, where the person to whom you speak has no right to know the truth, or more properly, where little or no inconveniency results from the want of confidence in such cases; as where you tell a falsehood to a madman, for his own advantage; to a robber, to conceal your property; to an assassin, to defeat or divert him from his purpose', see Moral and Political Philosophy (first published in 1785), Bk. III, Ch. 15, quoted by J.S. Mill in an editorial note at Rationale of Judicial Evidence, I, 233-34 n.
} 
the notion of verity as persuasion pointed to what was known about the physical world. In the former sense, truth was just what existed; it was in the latter sense, in the form of knowledge, that truth and utility interacted.

In his writings on logic, for instance, Bentham defined logic as 'the art, which has for its object or end in view, the giving to best advantage, direction to the human mind and thence to the whole human frame, in pursuit of any object or purpose, to the attainment of which it is capable of being applied'. ${ }^{2}$ Just as every art and science had well-being for its ultimate end, so did logic: 'logic, ... like everything else, is not any otherwise nor any further deserving of regard, than in so far as it is, or is capable of being, of use'. Bentham explained that the only intelligible meaning of 'use' was the capability to contribute to the diminution of pain or the increase of pleasure. ${ }^{83}$ Truth, in the shape of logic, was, therefore, subordinate to utility. It is worth reiterating, however, that the truth that Bentham had in mind was not 'absolute truth', but truth as persuasion. Bentham did not waver from his view that there existed a physical reality, and that knowledge was concerned with that physical reality: 'The existence of any expressible state of things, or of persons, or of both, whether it be quiescent or motional or both, at any given point or portion of time, is what is called a fact-or a matter of fact.' Hence, to say that one was persuaded that a 'recollection', that is a report of facts, given by a person was 'the truth' was to say that one was persuaded of 'the actual existence-of the supposed matter of fact the existence of which was the subject of the report in question'. ${ }^{84}$ Logic was concerned with the way in which the facts that existed in the physical world were organized according to certain operations performed by the human mind. Classification was not a property of the facts themselves ${ }^{85}$ Logic was indeed subordinate to utility, but logic was not physical reality-it was not truth in the sense of 'absolute truth', but in the sense of knowledge.

The fundamental assumption of Bentham's philosophical system was that there was a physical world that was experienced by sentient creatures. The motions and states of rest that took place in that world was the 'absolute truth'. The aim of the language developed by sentient creatures, insofar as they were sincere, was to reflect within their own minds on whatever part of that truth they had experienced and to convey that experience and reflection to the minds of other sentient creatures. These sentient creatures were more likely to promote utility (or rather their own utility) insofar as they possessed a greater rather than a smaller stock of truth, that is correct and complete beliefs concerning those facts. Having said that, a person in possession of truth did not necessarily strive to promote general utility. The creatures who experienced physical reality, and discoursed about it, were not simply passive recipients of data, but active assessors and judges of that data, and were influenced by such factors as sinister interest, interest-begotten prejudice, authority-begotten prejudice, and intellectual weakness. ${ }^{86}$ A person motivated by a particular and sinister interest would act in a way that promoted his self-interest rather than the general interest, and the greater the knowledge possessed by that person, the better able he would be to promote it. Such a person might find it to be in his interest to promote false beliefs amongst others. Hence, true

\footnotetext{
82 UC ci. 92 (3 August 1814).

${ }^{83}$ UC ci. 108 (25 September 1814). See also UC ci. 312 (5 August 1814), where Bentham stated that methodization, one of the most important logical operations, bore an indispensable relation to the end or purpose to which it was or ought to have been directed. In other words, the process of methodization was not a morally neutral operation that resulted in a value free description of some aspect of the universe, but had a point that had some value, and was undertaken with operations that might be better or worse conducted.

${ }^{84}$ UC cii. 301-02 (2 August 1814). See also UC cii. 15 (25 September 1814), where Bentham stated that to suppose the non-existence of certain corporeal substances could have painful consequences. If I did not believe in the existence of the projectile heading towards me, and so did not step out of its way, the resulting bruise would be painful. A corporeal substance that existed did so whether or not I believed in its existence (UC cii. 75 (3 October 1814)).

${ }^{85}$ See Jeremy Bentham, Chrestomathia (CWJB), edited by M.J. Smith and W.H. Burston (Oxford, 1983), 26174.

${ }^{86}$ See Jeremy Bentham, The Book of Fallacies (CWJB), edited by P. Schofield, (Oxford, 2015) 44-52, 197-98, and Bentham, First Principles, 151-52, 178-83.
} 
knowledge in this case did not promote the greatest happiness of the greatest number, but the greatest happiness of a lesser number. Bentham, then, appears to combine an objectivist ontology with a subjectivist epistemology, reflecting the notions of 'absolute truth' and truth as persuasion respectively. To summarize, wholly inadequately of course, in three short propositions, Bentham's position on the relationship of truth and utility: 'absolute truth' was physical reality; 'subjective truth' was the knowledge of that reality possessed by sentient creatures; and utility determined what that knowledge was worth. Bentham, then, had a correspondence theory of truth to the extent that a true proposition was one that accurately reflected physical reality. He had a pragmatic theory of truth to the extent that true knowledge was invariably conducive to the possessor's utility and that knowledge that had no bearing on utility was not worth knowing. He had a coherence theory of truth to the extent that persuasion of the existence of a principal fact depended upon persuasion of the existence of evidentiary facts, and perhaps also on the tendency at least of utility and truth to coincide. It appears that none of what today are accepted as the main theories of truth capture the richness of Bentham's analysis. 


\section{Top Heading (Arial 11 pt bold)}

This is the UCL Discovery typesetting template for author prepared papers deposited via RPS or alternative means. The template should be applied to all textual research outputs that can be edited, with the exception of e-theses, overlay journal articles and other outputs prepared to a designated template. Body text is all Arial 11 point regular with no first line inserts or hanging. Space is 0 (zero) points before or after, with no line spacing.

This is the UCL Discovery typesetting template for author prepared papers deposited via RPS or alternative means. The template should be applied to all textual research outputs that can be edited, with the exception of e-theses, overlay journal articles and other outputs prepared to a designated template. Body text is all Arial 11 point regular with no first line inserts or hanging. Space is 0 (zero) points before or after, with no line spacing.

Lower heading (Arial $11 \mathrm{pt} \mathrm{regular)}$

This is the UCL Discovery typesetting template for author prepared papers deposited via RPS or alternative means. The template should be applied to all textual research outputs that can be edited, with the exception of e-theses, overlay journal articles and other outputs prepared to a designated template. Body text is all Arial 11 point regular with no first line inserts or hanging. Space is 0 (zero) points before or after, with no line spacing.

\section{Top Heading (Arial 11 pt bold)}

This is the UCL Discovery typesetting template for author prepared papers deposited via RPS or alternative means. The template should be applied to all textual research outputs that can be edited, with the exception of e-theses, overlay journal articles and other outputs prepared to a designated template. Body text is all Arial 11 point regular with no first line inserts or hanging. Space is 0 (zero) points before or after, with no line spacing.

This is the UCL Discovery typesetting template for author prepared papers deposited via RPS or alternative means. The template should be applied to all textual research outputs that can be edited, with the exception of e-theses, overlay journal articles and other outputs

Page 3 - - >

prepared to a designated template. Body text is all Arial 11 point regular with no first line inserts or hanging. Space is 0 (zero) points before or after, with no line spacing.

Lower heading (Arial $11 \mathrm{pt} \mathrm{regular)}$

This is the UCL Discovery typesetting template for author prepared papers deposited via RPS or alternative means. The template should be applied to all textual research outputs that can be edited, with the exception of e-theses, overlay journal articles and other outputs prepared to a designated template. Body text is all Arial 11 point regular with no first line inserts or hanging. Space is 0 (zero) points before or after, with no line spacing. 